\title{
EMERGING PARTNERSHIP PRACTICES IN VET PROVISON IN THE SENIOR YEARS OF SCHOOLING IN AUSTRALIA
}

\author{
Dr Malgorzata Klatt \\ Senior Lecturer, Centre for Vocational and Educational Policy, the University of \\ Melbourne, 100 Leicester St, Carlton, Australia \\ klattm@unimelb.edu.au \\ +61390354975 \\ Dr Teresa Angelico \\ Senior Lecturer, Melbourne Graduate School of Education, the University of \\ Melbourne, 100 Leicester St, Carlton, Australia \\ Prof John Polesel \\ Director, Centre for Vocational and Educational Policy, the University of Melbourne, \\ 100 Leicester St, Carlton, Australia
}

\begin{abstract}
School partnerships support the effective provision of Vocational Education and Training (VET) in the senior years of secondary schooling, to a varying degree, in most OECD nations. However, the nature and quality of these partnerships vary considerably from school to school and, indeed, from nation to nation (see Murray and Polesel 2013). Given the role of these partnerships in VET provision in the senior years of schooling, it might be argued that there has been limited discussion about the role and nature of these relationships and the challenges associated with their establishment and long-term sustainability, especially in the Australian context (Allison et al. 2006). This paper explores the emergence of partnerships in a variety of educational and training contexts in Australia and describes the types of partnerships that have been established to respond to the specific needs of students. It also identifies the benefits and challenges associated with the delivery of VET programs through partnerships and the ways in which these partnerships can be developed and sustained to improve VET provision.
\end{abstract}

\section{EMERGING PARTNERSHIP PRACTICES IN VET PROVISON IN THE SENIOR YEARS OF SCHOOLING IN AUSTRALIA}




\section{INTRODUCTION}

School partnerships support the effective provision of Vocational Education and Training (VET) in the senior years of secondary schooling, to a varying degree, in most OECD nations. They do so by building capability at the local level (Clemans et al. 2005) and by enhancing student learning outcomes through targeted and tailored educational services to young people. School partnerships also involve working with partnership brokers, local businesses offering work-placements, external vocational education providers such as Technical and Further Education (TAFE) Institutes in Australia, and other non-educational and community institutions, to enable localised approaches to the provision of joined up VET services (Polesel et al. 2016).

However, the nature and quality of these partnerships vary considerably from school to school and, indeed, from nation to nation (see Murray and Polesel 2013). Given the role of these partnerships in VET provision in the senior years of schooling, it might be argued that there has been limited discussion about the role and nature of these relationships and the challenges associated with their establishment and long-term sustainability, especially in the Australian context (Allison et al. 2006). This paper explores the emergence of partnerships in a variety of educational and training contexts in Australia and describes the types of partnerships that have been established to respond to the specific needs of students. It also identifies the benefits and challenges associated with the delivery of VET programs through partnerships and the ways in which these partnerships can be developed and sustained to improve VET provision.

Central to the theoretical perspective underpinning the research is the concept of 'social partnerships', which provides a mechanism for both supporting educational and training needs at the local level through collaborative action (Clemans et al. 2005) and also for building social capital (Billett et al. 2007). Furthermore, this paper draws on the theoretical framework of Hall and Soskice (2001) which argues that different approaches to the delivery of vocational education and training have arisen in different OECD contexts, and that this mix of approaches relates to differences in the varieties of capitalism and the forms of the welfare state that exist in these different contexts. In brief, this research postulates a spectrum of approaches to VET provision, with neo-corporatism at one end, involving strong partnerships between providers, employers and other social partners to train workers, and neo-liberalism at the other end, exporting jobs or recruiting labour trained elsewhere, as 
market forces dictate. It also draws on the seminal work of lannelli and Raffe (2007) which postulated two 'logics' of vocational education - employment logic and education logic which map neatly to the two ideal forms of capitalism. These frameworks are used to identify and contextualise the types of school partnerships that have emerged within the current operational, policy and research context in Australia; and to articulate the essential practices that are needed to facilitate the effective implementation of partnerships in the senior years of schooling.

This paper begins with an exploration of the significance of partnerships and outlines the conceptual and theoretical perspective underpinning this research paper. It continues with an outline of the methodology and presentation of the key research findings, that is, the development of diverse partnership practices in the senior years of schooling as evident through the identification of distinct types of partnership conceptualisations, including the description of their characteristics and the identification of their reported benefits. This paper concludes with confirmation of the significance of school partnerships in supporting the provision of VET in the senior years of secondary schooling, a discussion of the challenges associated with school partnerships, and the identification of implications for action and further development.

\section{SIGNIFICANCE OF SCHOOL PARTNERSHIPS}

In the current policy context in Australia and internationally, there is a growing emphasis on developing good practice models of educational cooperation, including the partnerships that schools form with their communities. This development is in the context of the changing role of education in the knowledge economy, in response to the transition from "an industrial to a knowledge based or learning economy and society" (OECD, in Allison et al. 2006, p. 6) and requires educational institutions to "develop new and different approaches" to facilitating the delivery of sustainable learning communities (Allison et al. 2006, p. 13). Interestingly, this development is reflected in the emphasis placed by the Anglophone group of policy-makers from the UK, US, Canada and Australia on partnership policy development. The US Federal Act of 2006 lists partnerships between schools, other educational institutions and businesses as a requirement "to enable students to achieve state academic standards, and career and technical skills, or complete career and technical programs of study" (Perkins 2006, p. 43). In Canada, school partnerships with employers and businesses are seen as "a policy solution" to growing youth unemployment (Taylor, 2006, p. 319), where schools and employers are equally accountable for employability results. 
In Australia, the growth of partnerships between schools, workplaces and community organisations has corresponded to a broad policy context across commonwealth, state and territory governments that sought to raise the Year 12 (or equivalent) school completion rate to 90 per cent by 2015 (Clemans et al. 2005; Davies 2012; Philips 2010). The Australian Government argues that the education of students is not just the responsibility of schools but also of the broader community (Australian Government 2015). The establishment of the National Partnership on Youth Attainment and Transitions strategy in 2009, designed to foster a strategic, whole of community approach to supporting young people through the development of partnerships between and among schools, business and industry, parents and community groups (DEEWR 2011), can be seen to reflect this conception of education. This strategy included initiatives for 15-19 year old Australians who had become alienated by conventional schooling settings, as well as more 'mainstream alternatives', including VET in School (VETiS), the Victorian Certificate of Applied Learning (VCAL) ${ }^{1}$, and the Flexible Learning Options (FLOs) ${ }^{2}$ in South Australia.

Furthermore, in the late 2000s, school industry partnerships were mandated by Australian Training Centres to support both the engagement of external providers and the reconceptualisation of the role and responsibilities of school leaders beyond the confines of their individual schools (Hay 2009). Researchers such as Hay (2009) and Hay and Kapitzke (2009) acknowledge the value of these partnerships as well as their role in the discourse of school to employment transitions.

The concept of partnerships between schools, parents, carers and families, the broader community, business and other education and training providers has therefore emerged as an important factor influencing student outcomes (Henderson 2011; Broadbent and Cacciattolo 2013). These partnerships are able to facilitate successful youth transitions through the provision of a variety of support services provided by community organisations in conjunction with those provided by schools. Moreover, reports from Australia (Principals Australia Institute 2012) and the US (Henderson 2011) suggest that, given the positive link between parental and community engagement and student results, attendance levels, attitudes and behaviour, school-community partnerships need to be integrated within the operational structures of schools.

\footnotetext{
${ }^{1}$ The Victorian Certificate of Applied Learning (VCAL) is an accredited secondary certificate for students in Years 11 and 12 in Victoria, Australia. It is a practical education stream, where students may work in a trade or part-time job on some days of the week and supplement this by doing a set course at school.

${ }_{2}^{2}$ The FLOs are designed for students disengaged from school. Each student has a qualified case manager assigned, and an individual learning portfolio used to study in a community space, or a school site.
} 
The research literature suggests that partnerships between schools, businesses and community organisations influence young people's participation in education and training, providing them with significant and long term benefits for their employability, health, wellbeing and lifelong earnings (Access Economics 2005; Australian Bureau of Statistics 2010; Lamb and Rice 2008). Examples of beneficial partnership arrangements include businesses, external training providers, partnership brokers, and cross-sectoral and interagency collaborations (Te Riele, 2012; Ogawa and Kim 2005; Polesel et al. 2016).

Several reports have argued that high quality partnerships ensure effective program delivery, particularly in relation to the provision of structured workplace learning (NCVER, 2011; Polesel et al. 2004; Stokes, Stacey and Lake 2006). These partnerships have a demonstrable positive impact on student learning (ACER 2011), achievement and school engagement (Lonsdale et al. 2011). However, the most common reported benefit relates to improved vocational outcomes for students (ACER 2011), through workplace learning; the development of employability skills; increased employment and apprenticeship opportunities; engagement in the community; and the development of self-confidence and wellbeing.

A variety of challenges are associated with establishing and maintaining partnerships, such as the coordination of services (Black et al. 2010; Connor 2006; YacVic 2011), the cost of service delivery (Connor 2006; Owen 2004) and the sustainability of these services (De Jong and Griffiths 2006; Mills and McGregor 2010; YacVic 2011). There is recognition that the effectiveness of school partnerships depends on how they are structured, established and managed, including the importance of having a common focus as well as the management of the partnerships (Soerensen and Torfing 2007; Billett et al. 2007).

Over the last decade the demand for improved policy frameworks and innovative approaches to school governance has increased in response to the emergence of partnerships in education and training (Ball 2007, 2012; Ball and Junemann 2012; Suggett, 2014). In the current policy context in Australia and internationally, there is a growing emphasis on developing good practice models of governance for improving the delivery of VET programs (Perkins 2006, p. 43) to reflect the involvement of multiple organisations and the sharing of ideas and resources. However, this emphasis reflects a policy discourse that makes schools and partners accountable for the achievement of improved transitions and lower youth unemployment, impacting negatively on school autonomy within a framework of stated decentralisation and increased monitoring and central control (Mifsud 2016). This also reflects an abrogation of responsibility on the part of the social partners, such as employers and industry bodies. 
In sum, the research literature shows that there is a wide range of partners and partnership practices supporting young people's education and training at the level of senior secondary schooling. However, there is still limited discussion of how and why these partnerships are enacted in senior secondary schooling in Australia, as well as the kind of benefits they have for students and the challenges and implications they may create for schools.

\section{CONCEPTUAL AND THEORETICAL PERSPECTIVE}

In this research paper, the concept of social partnerships is used as a theoretical frame for understanding the partnership types, purposes and challenges currently apparent within the senior years of secondary education in Australia. A social partnership is therefore "an organizing concept for a range of practices" (Turner, 1994, p. 83) that reflect a "shared commitment to collaborative actions and decision making" associated with objectives of importance to the members of the partnership (Seddon and Billett, 2004:10). It is a "structural configuration characterised by the co-presence of different social subjects and reciprocal and collaborative action that seeks to achieve project goals" (Boccacin et al. 2011, p. 241).

Moreover, a social partnership is an organisational or social process that develops in response to the synergy produced in partnerships and is "distinct from hierarchical and market types of organisations" (Boccacin et al. 2011, p. 245). Social partnerships may arise in response to top down initiatives or may be an outcome of bottom up dynamics (Boccacin et al. 2011, p. 247). They develop over time and therefore reflect different characteristics at different stages.

The concept of social partnership has emerged not only as a mechanism for supporting local needs and circumstances through collaborative action, for example by securing effective educational provision (Clemans et al. 2005, p. 1), but also for building social capital. The role of social capital in community development and sustainability has been explored since the early 1990s (Allison et al. 2011). It is considered to be essential for sustaining partnerships (Billett et al. 2007), through the creation of cooperative relationships based on trust (Boccacin et al. 2011). These relationships may be built through networks that 'link' social capital by enabling school personnel to leverage a wider range of resources than those available in their school (Woolcock, 2001).

The operation of partnerships, however, is also highly dependent on the political frameworks 
within which they operate. Hall and Soskice (2001) argue that the role played by employers and the other social partners, such as chambers of commerce and trade unions, is crucial in the delivery of vocational education. They argue that, in neo-corporatist or coordinated market capitalist economies, such as Germany and Denmark, the effective provision of vocational education depends on an underlying 'accord' between schools, employers and other social partners. This 'accord' is not simply the partnership itself but the deeper underlying principles which govern it, based on an understanding that they can derive competitive advantage from training highly skilled workers in their own system, through a mutual and beneficial dependence that develops between education and training providers, employers and other social partners. By way of contrast, neo-liberal market economies such as Australia and the other Anglophone nations noted earlier in this paper have seen a decline in the strength of these partnerships, accompanied by a steep decline in apprenticeships and an accompanying rise in the dependence on imported skilled labour or the actual export of jobs. Linking these theories to lannelli and Raffe's (2007) work, we might argue that neo-corporatist economies have adopted an 'employment logic' in the delivery of VET, linking skills formation closely to the workplace where it will be used, through strong, apprenticeship-based programs that are jointly funded by employers and providers. On the other hand, neo-liberal economies, like Australia, have adopted an 'education logic' in the delivery of VET, with most VET being campus-based rather than work-based and with limited commitment or co-investment by employers. These are important contextual factors which need to be kept in mind as we explore the complexities of collaboration and as we seek to identify not only the desired outcomes of partnerships but also the issues and barriers to the achievement of these objectives.

\section{METHOD}

The data presented in this paper were collected as part of a broader project exploring the role that partnerships play in the senior secondary school curriculum in Australia. This Australian Research Council funded project is titled: Innovative partnerships for youth engagement in education and work (LP120200272). This research paper draws on over 30 in-depth, semi-structured interviews with school principals, teachers and program coordinators and 30 focus group meetings with 134 students conducted in 2015 in metropolitan and regional secondary schools located in the states of Victoria, South Australia and New South Wales.

The interview and focus group questions were divided into three main themes. The first 
theme addressed the importance of understanding the context of each school (location, programs offered, type of students), in order to identify the needs of students and the ways in which VET can be delivered through a partnership arrangement to meet these needs. This theme was informed by an exploration of the ways in which school contexts influence the partnerships. The second theme addresses the importance of identifying purposes and motivations for the establishment of partnerships. Participants were asked to identify the main drivers for engaging partners and their conception of a successful partnership. Finally, the third theme explores the benefits and challenges associated with the delivery of VET through partnerships and the implications for improvement and sustainability.

The study was also complemented by a school survey conducted in 2014 . This survey was designed to investigate school leaders' experiences and perceptions relating to approaches to applied learning, the institutional support for and barriers to these approaches, and the nature of partnership experiences, including the school leaders' views on ways of improving the delivery and management of these programs. The survey targeted all secondary schools that provide applied learning and VET programs (State, Catholic and Independent) across the three states and was conducted online through Survey Monkey. Schools were selected and invited to participate via email contact from the industry partners (state, Catholic and independent school agencies), which used their contact databases for this purpose. There were 1558 secondary (or combined) schools in all three jurisdictions with 1137 schools invited to complete the survey. Of the 1137 schools, 215 completed responses were received, resulting in a 19 per cent response rate. The state and sector distribution is provided in Table 1 below.

Table 1 Survey participation by state and school sector

\begin{tabular}{|l|c|c|c|c|c|c|c|c|}
\hline Jurisdiction/Sector & \multicolumn{2}{|c|}{ State } & \multicolumn{2}{|l|}{ Catholic } & \multicolumn{2}{c|}{ Independent } \\
\hline & Total* & Surveyed & Total* & Surveyed & Total* & Surveyed & Total* & Surveyed \\
\hline Victoria & 320 & 55 & 99 & 25 & 150 & 10 & $\mathbf{5 6 9}$ & 90 \\
\hline New South Wales & 434 & 36 & 157 & 25 & 224 & 24 & $\mathbf{8 1 5}$ & $\mathbf{8 5}$ \\
\hline South Australia & 141 & 30 & 33 & 10 & N/A & N/A & $\mathbf{1 7 4}$ & $\mathbf{4 0}$ \\
\hline
\end{tabular}




\begin{tabular}{|l|l|l|c|}
\hline Total & & 1558 & 215 \\
\hline
\end{tabular}

*Total number of secondary and combined (primary and secondary), 2010-16, ABS 2016.

\section{Partnerships for VET in Australian secondary schools}

Although it would seem that all secondary schools in Australia formed partnerships to meet the needs of VET provision, and to achieve the broader policy objectives (retention and engagement), various partnership types were observed by this research. The schools that participated in the research study had established partnerships that serve a very diverse range of students, reflecting differences in location, socio-economic status (SES), the number of Indigenous students and different school sectors. All these factors have influenced the rationale and shape of the partnership arrangements. Our analysis of the research data suggests that there are three principal motivations in the formation of partnership arrangements in the senior secondary years of schooling. These motivations overlap and vary in importance in the different schools, but all are evident in one form or another in the majority of the schools that participated in this research project, irrespective of the jurisdiction or school sector.

The following section explores each of these rationales and the ensuing partnership types as experienced not only by school representatives (principals, VET coordinators, teachers etc.) but also by students and partnership organisations; as well as how such partnerships impacted on schools.

\section{Type 1 - Partnering for delivery of VET Programs}

Schools offering VET often may need a partner that delivers VET programs and this is therefore the most common type of partnership. This partnership plays an important role in providing technical skills, technical expertise and infrastructure enabling students to achieve better educational and transition outcomes.

Schools partner with various VET providers (public and private) in order to deliver the applied learning or vocational education programs. Some schools have designated Trade 
Training Centres ${ }^{3}$, and in these sites, school teachers deliver the programs. However, external providers may still be required, due to the wide range of programs offered by schools. One principal explained:

It's a very, very large sourcing of organisations providing the training so at any one time I think we're dealing with up to 12 to 15 RTOs [Registered Training Organisations] for the classes and then all the ones for the school based apprenticeships on top of that.

The majority of schools that participated in the research project utilised a mixture of different providers, including a variety of delivery modes (e.g. on-site, off-site). Over 80 respondents (37 per cent) confirmed that they had an auspicing arrangement with a partner where the school delivered programs on-site, acting as private training provider. This required schools to secure space, infrastructure, equipment and specialised teaching staff. Schools that have Trade Training Centres shared their facilities with other schools and providers, bringing another layer of complexity to the arrangements, as indicated by one of the interviewees:

The VET provision is incredibly complex given the shared facilities and the Trade Training Centre consortium and other schools actually using that facility, so that's really, really tightly put together.

At the moment anyone working in the VET area, especially if they're in a lead school for a Trade Training Centre, has got an enormous job on their hands. It's very difficult work keeping all of the mix in play. (It's) very difficult work.

In order to deliver programs in partnership with training providers, the research participants indicated that there was a need to adapt the 'traditional school structures', such as timetables and coordination arrangements. These adaptations included working collaboratively with other schools to establish viable cross-school student classes delivered by selected providers, as well as creating new staff roles within schools to coordinate and maintain essential partnerships.

\footnotetext{
${ }^{3}$ The Australian Government has invested nearly \$1.4billion from 2008-2016, through the Trade Training Centres in Schools Program to enable secondary school students to have access to modern trade training facilities. Eligible schools access funding to build new or upgrade existing trade or vocational education and training facilities, and to equip those facilities with industry standard equipment (Australian Government, 2014).
} 
It is clear from all the research data that building partnerships for VET delivery requires significant commitment, time and effort from school staff. Participants suggested that schools built their capacity to respond to the diverse range of student needs and expectations by accessing a variety of providers and broadening their curriculum offering. Students in secondary schools across Victoria, South Australia and New South Wales had over 80 different programs to choose from, ranging from furniture making to financial services. Schools wanted to "give the guys options for what takes their fancy" (VET coordinator from Victoria). Therefore, the role of the school-provider partnership would be to deliver the courses corresponding with students' choices. Nevertheless, the increased number of partners and courses requires more resources to engage and manage students' learning progress and ensure their well-being.

Students interviewed for this study recognised the value of learning with different providers as well as the capacity for these programs to retain them in education programs. One of the recurrent themes that emerged from these interviews was the motivation for selecting specific VET courses. Many students indicated that they chose their VET course because it was the best option available to them and it catered for their interests, such as working with children or animals, or in construction or hospitality. Several students explained their choices:

I probably would've dropped out in Year 10 but I started VCAL in Year 10. That's the only reason I stayed at school. To stay in that class.

I wake up every morning and just be like 'I feel I can't wait to come to school because I know my class is going to be good.'

Students considered the applied learning pathway to be appropriate for them because it provided a better approach to learning. In the words of one student, "(F)or a lot of people it's the best way to learn". It is considered to be an easier way to study:

The schoolwork we're doing is easy. It's not as complex or confusing as other subjects, like science.

So I found that this would be easier to cope with that's easier for me, I suppose. I understand it.

It's easier because it's what we want to learn.

Applied learning is seen to provide a better balance between theoretical and practical learning and to enable the practical application of theory. 


\section{Type 2: Partnering to provide Structured Work-Placements}

Most schools in the study had also established partnerships with local businesses to provide their students with structured workplace learning opportunities. Structured workplace learning is on-the-job training during which a student is expected to master a set of skills or competencies that lead to an industry specific VET qualification that is recognised throughout Australia.

The research data indicate that local businesses were the largest non-educational partner to be involved with schools. One of the school principals explained that their contact base with employers is "almost an ever expanding pool" because of the significant demand for placements. For over 60 per cent of respondents the school's own networking played the most significant role in initiating partnering arrangements - some schools created databases of local employers, or organised 'job carnivals' where students could meet representatives from local industries. Increasingly, schools appointed industry coordinators to manage the relationships with employers:

I go out with [our Industry Consultant] once a term and visit the employers ... he is a connection to lots of people within the area and knows it, so that's a sort of a partnership, that he helps us to be sustainable.

One of the schools established a formal industry board, which included school staff and the local industry representatives. The board assisted the school with planning and designing vocational courses and training:

A formal industry board, which turned out to be the greatest 'God-send', I think, for the College in terms of strengthening the future (...) it's great to have the industry to test that against ... to get feedback from.

The majority of the school principals understood that vocational programs were closely linked to employment and post-schooling VET pathways and that providing these students with industry exposure within the VET pathway of their choice was an important objective of the school. Nevertheless, schools acknowledged that the partnerships with employers required constant attention:

You've got to keep your employers on board. That takes a lot of work. You've got to be so careful with them. You've got to nurture them. 
Similarly, the demand on industry partners was also recognised, as schools struggled with finding placements, as expressed by one of the school principals: "There's a lot of weariness from employers from taking on countless numbers of students".

Almost all school staff agreed that the students appreciated work-placements. Responses from students also revealed a highly positive picture of their work experiences undertaken in a diverse range of industries, such as music studios, trade environments, early learning centres, manufacturing, cafes, pharmacies, accounting firms, libraries, farms and building sites.

Through work-placements or apprenticeship programs students explored job options in particular occupations. They valued the opportunity to learn new skills and develop knowledge about workplaces. Furthermore, some students considered the vocational pathway to be superior to the general academic pathway because it: encourages them to work out what they want to do after they leave school; enables them to be employed full time when they leave school, providing them with an income; and provides them with work experience and qualifications.

So, we're leaving (school) ... further ahead ... with more experience.

We leave with the qualification. If they [VCE students] fail ... they've got nothing ...

They're about to leave school and they don't know what the workforce is going to be like!

Students also explained that working in the 'adult' environment "made you grow up a lot quicker" as you need to "behave like an adult when they treat you like an adult".

The industry representatives interviewed for the purpose of this study appreciated their own input into the professional and personal development of those young people:

You can mould them ... those 16 years olds, they are not fixed yet on what they want, what they like. You can help them form their 'professional self'. We help them mould their 'professional self'. They are young so it's beneficial, as they are more open on learning from industry.

\section{Type 3: Partnerships for engagement and wellbeing}


Over half of the respondents reported being partnered with at least one community organisation. Many school leaders emphasised the importance of the involvement of local community organisations in schools, particularly within the VCAL program. The schools located in highly disadvantaged communities with large enrolments of kids from low socioeconomic-status (SES), refugee or Indigenous backgrounds emphasised the importance of partnerships that helped reduce disadvantage.

When asked about partnering with the community organisations several school representatives emphasised the broader goals of these links. Some stated that the key goals were the development of "well rounded young people", "lifelong learners", and "community citizens" as well as partnerships with local community; these partnerships were seen as effective in engaging young people in social issues.

One of the VET coordinators interviewed emphasised the importance of VET in terms of addressing and minimising the disadvantage the students bring with them:

We push towards VET and partnerships to solve the problems of our kids of low socioeconomic status.

Schools responded to the needs of their most disadvantaged students by helping them to develop essential skills through the provision of educational opportunities made available through a wide variety of collaborative partnerships.

A lot of these kids get exposed to illegal activity. Some live on the street. The school is their only place of security and warmth and nurturing. On the brighter side it gives you massive potential to do the most marvellous programs with the kids and the community. The potential is enormous.

In order to support students' personal development and engagement in education, schools partnered with a range of local community organisations such as Red Cross, community groups or local councils. Typically students would be involved in helping to solve local issues or organising local events. For example, one of the schools had responsibility for organising a local surf festival involving over 120 students:

Students are involved in every aspect of the event from the catering, multimedia and marketing teams, judging area, photography, building the compound and administration.

Other projects involved building plant boxes and children's toys for charities, organising walk-a-thons, BBQs and other fundraisers for the local community. One of the schools in 
NSW developed a strong partnership with Google and a known marine activist to tackle local environment issues. As part of the project, students had to build an underwater robot that would be operated from inside the biosphere. The robot operations were to be broadcast via 'Google classroom' across the world. Such collaborations required school teachers and students to develop and show a variety of entrepreneurial skills such as project planning, project management and risk assessment. Research participants identified a number of personal development benefits including: students' increased self-esteem and sense of belonging; strengthened communication skills and the building of students' aspirations.

One of the school principals also suggested that access to partners enables the school "to understand our students and what supports are out there". As one of the most popular training packages for VET in schools is 'Sport, Fitness and Recreation', various sporting clubs are engaged with schools. These sporting clubs not only deliver training courses but in some cases also provide mentoring to minority groups such as refugees. Such mentoring programs built connections within the school and outside the school:

For kids who don't have parents, who may not have any family in Australia, they've got a link outside of school because typically our refugee kids come to school because this is a place where they belong ...

The research data suggest that through partnerships, schools are able to develop strong links with community organisations to support equity initiatives for disadvantaged and disengaged students. These links support schools to develop their social capital and utilise collaborative advantage to meet the needs of students. Through the development of shared values and understandings, schools are able then to collaborate on agreed goals for young people in their local communities. Nevertheless, the creation of new links requires additional resources, as well as new skills from teachers. For example, over 70 per cent of respondents believed that a motivated teacher - "champion of VET" - played a significant, or highly significant role in maintaining these programs, and that required "high level communication skills", "a capacity to empathise with students" and the ability to "understand psycho-social factors". Some schools engaged youth workers who worked across agencies to broaden the resource base for their educational delivery. One of the schools in South Australia organised school trips with youth workers, including visits to Aboriginal communities and rainforest walks. Another school with about 50 Indigenous students partnered with a local industry broker, who was successful in getting additional funding for the placement program for Indigenous youth. The deputy principal emphasised that building links between curriculum and student welfare was part of their "obligation to engage and build resilience so these young people can be provided with broader perspectives." 


\section{DISCUSSION}

The findings of this study confirm the significance of school partnerships in supporting the provision of VET in the senior years of secondary schooling and the attainment of desired student learning outcomes. Three distinct partnership types have emerged in response to the diverse needs of students and actions taken at the local level. The largest and most important partnerships are those formed with other VET providers and employers, reflecting recent policy emphasis on the kinds of school partnerships that support VET provision. In Australia, neo-liberal economic policies and the delivery of VET programs within the lannelli and Raffe (2007) education logic paradigm has seen limited involvement or contribution from employers or industry, meaning that effective partnerships have proven challenging to establish.

The provision of VET means curriculum provision requires collaborative structures that involve the wider community in learning and skills development. The most visible and, arguably, the most important of these innovations are the applied learning programs that have been introduced into all senior certificates in Australia and which require the building of partnerships with external providers and employers. Thus the quality of VET delivery is shaped by the nature and quality of the interactions between the actors (teachers, coordinators, training providers, private enterprises, local government, or youth case managers).

\section{Neo-liberal market choice principles}

The impetus for secondary schools in Australia to create partnerships comes from a policy framework that links educational goals to partnerships with a range of providers and community organisations. This means the aims of some partnerships may be focussed narrowly on the immediate learning needs of students and not on an in-depth consideration of the role of the partnership, including the specific responsibilities of the partners. Given this focus on student learning outcomes, the majority of schools in our study offered VET courses on the basis of student choice "or what takes their fancy" (VET coordinator from Victoria). This market-based education approach is problematic, as it is based on the premise that a student has adequate knowledge of course pathways, career possibilities and opportunities within the education system and the labour market. We know from previous research that the majority of students undertaking VET in schools come from a lower SES background (Polesel 2008) and as a consequence these students make decisions within the confines of the opportunities available to them. Students from disadvantaged backgrounds are more likely to participate in courses that provide a direct pathway to work, without further 
formal education or training, despite the limited range of jobs available for unskilled, unqualified youth. While the choice and flexibility offered by vocational programs may contribute to higher levels of student engagement and attendance at the school, successful transition of students from school to further education and training may be jeopardised. Students need meaningful career development advice, including information on educational pathways and data related to the expected labour market outcomes for their selected occupation. A recent study suggests that students also require a coherent program of foundational disciplinary knowledge and skills (Clarke 2013) in order to achieve coherent, transparent pathways from school to intermediate and higher level qualifications.

A common understanding is also needed between schools and partners about the selection of VET courses and the capacity of VET providers to support students' interests and capabilities. As O'Flynn and Wanna (2008) note, to facilitate collaborative advantage, organisational culture and decision-making need to be driven by consensus and agreement, shared understandings and collaborative action. This dialogue needs to be around the delivery of educational services that take into account current and future labour market needs, the contribution of VET providers, and the ability of the school and the VET provider to link course content to a relevant and meaningful work-placement. There needs to be recognition that a 'sizable' workplace learning component plays an important role for students' work related skills and labour market outcomes (Black, Polidano and Tabasso 2011). In order to integrate workplace learning in educational delivery, partners need to: be well informed about how schools operate in the current environment; identify ways in which their interests are catered for in the partnership; and define the approach to collaboration (Salamon 2000). The combination of these factors would help students make more informed post-school choices. In a neo-liberal economic framework such as Australia's, the interaction of the school's partners is limited and is not supported by a framework of nationally agreed and shared interests and commitments. This makes it dependent on good will, the quality of negotiators in schools and the employers and external providers with which they work, and the emergence of trusting relationships.

\section{The impact of an education logic}

The dominance of assessment regimes (see: Stevens et al. 2011; McNeil et al. 2008) is a prime example of education logic in the design and delivery of VET courses in Australian schools. It has resulted in the marginalisation of partners from this process and has also contributed to the marginalisation of VET courses within the broader offerings of secondary schools in Australia. 
As schools have limited capacity to adapt curriculum and pedagogy to the needs of all students, the VET curriculum has served as an avenue for broadening options for students. The majority of the students we interviewed indicated a preference for undertaking VET courses due to their 'hands on' learning style. The preference for the 'hands-on' learning style was a prevalent theme in our conversations with these young people. Te Riele and Crump (2002) argue that what may be underpinning students' desire for practical studies is their experience of learning as 'foreign' and non-applicable to their needs and day-to-day lives. Students tend to construct self-identities based on their perceptions of their abilities, strengths and aspirations and select particular pathway options because they see these as providing a 'better match' with their self-identity (Anlezark et al. 2006; Atweh et al. 2005). They use their early performance to update their beliefs about their fit with particular pathways and these beliefs in turn influence further decisions (Kreisman and Stange 2015). Lower performing students see applied learning subjects as being a better fit for them because they build on their interests and capabilities and help them develop and apply knowledge and skills (Te Riele and Crump 2002). By selecting pathway options based on an assessment of best fit for them, students reinforce self-fulfilling prophecies and deficit views of themselves as learners. Their responses suggest that applied learning is preferable as it incorporates experiential, hands-on, active learning and work-based learning approaches.

However, the application of an education logic to the design and delivery of school-based vocational programs has meant that the links between qualifications and employment are weak, and the boundaries between vocational and academic curricula in schools poorly signposted. In the words of lannelli and Raffe (2007: 5), this means that vocational education is defined more "by its lower status than by its stronger orientation to employment". Traditional hierarchical structures of schooling contribute further to the lowering of the prestige of vocational programs. Although the schools in our study have embraced the opportunities created by the broad network of partners, they have not necessarily changed their organisational, management and administrative structures. Schools need to transform their structures to enable them to deliver a broad curriculum that caters for a wide range of needs and interests. They need to align their practices with internal and external structures and norms to facilitate the collaboration needed for delivery of joined up VET services (Wanna 2008). For example, schools perceived the question of flexible timetabling as the most important issue impacting relationships with external partners. Responses from participants suggest that some schools are resistant to change and believe that external partners should adjust to school structures. Another example is the increasing demand for structures designed to support career-development and post-school transition pathways. 
These views suggest that the cooperative arrangements needed for effective VET provision do not incorporate a truly 'corporatist' view of the VET mission as a shared task.

Challenges associated with this alignment reflect a broader tension between a marketoriented approach to program provision (with education logic informing its design) and the traditional inner-workings of schools. Two contrasting developments are evident. On the one hand, schools present as active players in an education market place (offering various programs, competing for students, being productive and accountable), and on the other hand, they are hampered by rigid structures that impact on their capacity to deliver, monitor, and support programs and student transitions.

Schools also need to ensure that their joint delivery efforts are sustainable over time. Responses from participants indicate that although some schools have long lists of employers (who from time to time are willing to provide some sort of work-placement) they do not have long-term, formalised partnerships with them. The formal involvement of local businesses within school structures was the exception rather than the rule in our study, as the majority of schools relied on the private contacts of parents and students.

There is a need therefore for schools to establish formal relationships with industry partners, allowing students to integrate theoretical and practical knowledge in workplace contexts and enabling schools to provide work placements in a cost effective manner. Although industry brokers (funded by state governments) were helpful, they did not always result in successful placements because they were not always able to take into account the inability of students to access public transport or travel long distances. Formal partnerships would enable schools more effectively and efficiently to manage the coordination and securing of work placements.

The requirement to deliver VET in the senior years of secondary schooling through partnerships has implications for school and community leaders who are responsible for building delivery capacity. This agenda, which is not unique to Australia (see Whitty and Wisby 2016), is complex and multifaceted.

The first element of this agenda is the importance of reconceptualising the nature and content of school education, including the place of VET in general education. Vocational and applied learning pathways need to be integrated within the overall provision of secondary schooling. This integration requires particular understandings, capabilities and skills to facilitate cultural change in schools (Eggers 2008) and more broadly the development and 
maintenance of partnerships. School leaders need to ensure that teachers are able to work collaboratively with external partners to provide targeted and relevant programs.

School and community leaders need also to ensure that 'enabling' partnership structures are created to maximise collaborative advantage by, for example, ensuring that the school timetable allows students to simultaneously access services provided by both the school and delivery partners. Our research has highlighted the critical importance of funding to support this delivery of curriculum through partnerships. School and community leaders need to ensure that funding is secured to provide students with access to quality work placements.

Finally, our study points to the need for formalising partnership arrangements to empower all partners to effectively engage in the delivery of VET services by supporting collaboration and coalition building (Wanna 2008). Governance models are needed to support the marketisation of VET options and to secure the resources needed to implement, deliver and monitor educational and training provision across the partnership. This suggests the approach needs to be corporatist and cooperative, rather than adversarial and competitive, and that it needs to be supported by national policy and governance frameworks.

\section{CONCLUSION}

This paper confirms the importance of partnerships in supporting VET provision in the senior years of secondary schooling to improve student learning outcomes, by providing targeted and tailored educational services to young people through a range of partnership arrangements, especially with employers and external providers. The concept of 'social partnerships' has been useful in providing a theoretical frame for conceptualising 'partnership' as an organisational or social process.

However, the theories of varieties of capitalism and education and employment logics suggest that 'social' partnerships need to be conceptualised more broadly to include the social partners traditionally associated with the smooth functioning of modern societies and economies - education providers, employers and the state. Our data, seen in the context of these theories, illustrate that the emergence of partnership types, including the benefits and challenges associated with them, are affected by the dominant education logic of delivery and neo-liberal economic framework that underpin VET systems in Australia.

A top down policy agenda in Australia focussing on the achievement of student learning outcomes has provided the impetus for the development of educational and training provision that is best delivered through strong partnerships. The development of these 
partnerships occurs at the local level and enables the building of social capital to support young people to make effective transitions from school. This highlights the role of leaders in facilitating a complex and multifaceted change process, and requires: a re-conceptualisation of the place of VET in the general school curriculum; the development of new understandings, capabilities and skills to build the capacity for delivering through partnerships; the creation of enabling delivery structures to maximise collaborative advantage and minimise inertia; and the critical importance of securing financial resources to improve the effectiveness and sustainability of VET delivery.

However, a real integration of the roles of schools, external providers and employers into an effective system of provision also requires a broader commitment from these social partners, including the state. These partnership practices are located within the context of the changing role of education in the knowledge economy and the current educational policy and operational framework (such as, the senior school curriculum, assessment regimes, and school management and timetabling structures). Our research shows that this policy and operational framework presents challenges for school and community leaders, and that these challenges cannot be fully addressed at the local level without broader support from all the 'partners' in the mission of educating our children.

\section{REFERENCES}

Access Economics (2005). The Economic Benefit of Increased Participation in Education and Training. In. Sydney: Dusseldorp Skills Forum.

Allison, J., Gorringe, S., \& Lacey, J. (2006). Building learning communities: Partnerships, social capital and VET performance. Adelaide: NCVER

Anlezark, A., Karmel, T., \& Ong, K. (2006). Have School Vocational Education and Training Programs Been Successful? Adelaide: NCVER.

Atweh, B., Taylor, S. \& Singh, P. (2005). School Curriculum as Cultural Commodity in the Construction of Young People's Post-School Aspirations. Paper presented at the Australian Association for Research in Education annual conference, University of Western Sydney, Parramatta.

Australian Bureau of Statistics (2010). Measures of Australia's Progress (No. 1370.0). http://www.abs.gov.au/ausstats/abs@.nsf/mf/1370.0.

Australian Bureau of Statistics (2016). Schools, Australia 2016 (No. 4221.0). http://www.abs.gov.au/AUSSTATS/abs@.nsf/DetailsPage/4221.02016?OpenDocumen $\mathrm{t}$

Australian Council of Educational Research (2011). Final Report: The benefits of schoolbusiness relationships. Melbourne: Department of Education Employment and Workplace Relations.

Australian Government (2010). Social Inclusion Principles for Australia. Canberra: Australian Government. 
Australian Government (2014). Trade Training Centres in Schools Program: 2014 progress Report. Canberra: Department of Education and Training.

Ball, S. J. (2007). Education plc: Understanding private sector participation in public sector education. Oxon: Routledge, Taylor \& Francis Group.

Ball, S. J. (2012). Global Education Inc.: New Policy Networks and the Neoliberal Imaginary: Oxon: Routledge, Taylor \& Francis Group.

Ball, S. J., \& Junemann, C. (2012). Networks, new governance and education. Bristol: The Policy Press.

Beck, J. (2013). Powerful knowledge, esoteric knowledge, curriculum knowledge. Cambridge Journal of Education, 43(2), 177-193, doi:10.1080/0305764X.2013.767880.

Billett, S., Ovens, C., Clemans, A., \& Seddon, T. (2007). Collaborative working and contested practices: forming, developing and sustaining social partnerships in education. Journal of Education Policy, 22(6), 637-656, doi:10.1080/02680930701625288. .

Black, D., Polidano, C., \& Tabasso, D. (2011). The Role of VET-in-Schools in School Completion and Post-School Outcomes. Melbourne: Melbourne Institute of Apllied Economic and Social Research.

Black, S., Balatti, J. O., \& Falk, I. A. N. (2010). Reconnecting young people with learning: A social capital approach in VET. [Article]. International Journal of Training Research, 8(2), 103-115.

Blake, D. (2007). Exploring the Challenge of Applied Learning Reform. International Journal of Pedagogies and Learning, 3(3), 58.

Boccacin, L., Rossi, G., \& Bramanti, D. (2011). Partnership, social capital and good practices among public, private and the third sector. Journal of US-China Public Administration, $8(3), 241-260$.

Broadbent, R., \& Cacciattolo, M. (2013). The role of school community partnerships in building successful transition pathways for young people: one school's approach. Australian Educational Researcher, 40(1), 109-123.

Clarke, K. (2013). Entry to the vocations: strengthening VET in Schools. Adelaide: NCVER.

Clemans, A., Billett, S., \& Seddon, T. (2005). Initiating, Developing and Sustaining Social Partnerships Through Partnership Work. In J. Searle, F. Beven, \& D. Roebuck (Eds.), Vocational Learning: Transitions, Interrelationships. Partnerships and Sustainable Futures (pp. 148-155). Brisbane: Australian Academic Press.

Connor, J. (2006). What's Mainstream? Conventional and Unconditional Learning in Logan. Sydney: Dusseldorp Skills Forum

Council of Australian Governments. (2009). National Partnership Agreement on Youth Attainment and Transitions. Canberra: Commonwealth of Australia.

Davies, M. (2012). School Partnerships: Connecting schools, workplaces, and communities. Paper presented at the COAG Reform Council's Good Practice in Youth Transitions National Conference, Adelaide, South Australia, 16-17 August 2012.

De Jong, T., \& Griffiths, C. (2006). The Role of Alternative Education Programs in Meeting the Needs of Adolescent Students With Challenging Behaviour: Characteristics of best practice. Austalian Journal of Guidance and Counselling, 16(1), 29-40.

Department of Education Employment and Workplace Relations (2011). The Compact with Young Australians. Canberra: DEEWR.

Eggers, W. D. (2008). The changing nature of government: network governance. In J. O'Flynn, \& J. Wanna (Eds.), Collaborative Governance. A new era of public policy in Australia? Canberra: ANU E Press. 
Hall, P., \& Soskice, D. (2001). An Introduction to Varieties of Capitalism. In P. Hall, \& D. Soskice (Eds.), Varieties of Capitalism: The Institutional Foundations of Comparative Advantage (pp. 1-70). Oxford: Oxford University Press.

Hay, S. \& Kapitzke, C. (2009). School industry partnerships: constituting spaces of global governance. Globalisation, Societies and Education, 7(2), 203-216.

Hay, S. (2009). Transforming Social and Educational Governance: Trade training centres and the transition to social investment politics in Australia. British Journal of Educational Studies, 57(3), 285-304. doi:10.1111/j.1467-8527.2009.00441.x

Henderson, A. (2011). Family-School-Community Partnerships 2.0 Collaborative Strategies to Advance Student Learning. Washington: National Education Association.

Huxham, C. (2003). Theorizing collaboration practice. Public Management Review, 5(3), $401-$ 423, doi:10.1080/1471903032000146964.

Iannelli, C., \& Raffe, D. (2007). Vocational Upper-Secondary Education and the Transition from School. European Sociological Review, 23(1), 49-63, doi:10.1093/esr/jcl019.

Kreisman, K., \& Stange K. (2015). Vocational and Career Tech Education in American High Schools: Curriculum Choice and Labor Market Outcomes. Working Paper. [cited with authors' permission].:

http://www.dkreisman.com/research/Kreisman Stange 2015.pdf

Lamb, S., \& Rice, S. (2008). Effective Strategies to Increase School Completion: Report to the Victorian Department of Education and Early Childhood Development. Melbourne: Department of Education and Early Childhood Development.

Lonsdale, M., Deery, A., Clerke, S., Anderson, M., Curtin, E., Knight, P., et al. (2011). Final report: the benefits of school-business relationships. Camberwell: ACER.

MCEETYA (2008). National Declaration on Educational Goals for Young Australians. In MCEETYA (Ed.). Canberra: the Ministerial Council on Education, Employment, Training and Youth Affairs.

McNeil, L.M., Coppola, E., Radigan, J., \& Vasquez Heilig, J. (2008). Avoidable losses: Highstakes accountability and the drop out crisis. Education Policy Analysis Archives, 16(3),1-48.

Mifsud, D. (2016). The policy discourse of networking and its effect on school autonomy: a Foucauldian interpretation. Journal of Educational Administration and History, 48(1), 89-112. doi:10.1080/00220620.2016.1092427

Mills, M., \& McGregor, G. (2010). Re-engaging students in education. Brisbane: Youth Affairs Network Queensland.

Murray, P. and Polesel, J. (2013). A comparative exploration of learning pathways and transition systems in Denmark and Australia. European Journal of Education, 48(2), 233-246.

National Centre for Vocational Education Research (2011). Young people in education and training 2009. Adelaide: NCVER.

O’Flynn, J., \& Wanna, J. (2008). Preface. In J. O’Flynn, \& J. Wanna (Eds.), Collaborative Governance. A new era of public policy in Australia? Canberra: ANU E Press.

Ogawa, R. T., \& Kim, R. H. (2005). The business-education relationship. Journal of Educational Administration, 43(1), 72-85, doi: 10.1108/09578230510577308.

Owen, C. (2004). Have we got what it takes?: The skills, rewards and recognition needed for teachers, youth workers and others in Learning Alternatives. Sydney: Dusseldorp Skills Forum.

Perkins, Carl D. (2006). Career and Technical Education Improvement Act of 2006. 
Washington: US Congress.

PhillipsKPA (2010). Unfolding Opportunities: A baseline study of school-business relationships in Australia. Canberra: Department of Education, Employment and Workplace Relations.

Polesel, J. (2008). Democratising the curriculum or training the children of the poor: school-based vocational training in Australia. Journal of Education Policy, 23(6), 615632, doi:10.1080/02680930802054420.

Polesel, J., Klatt, M., Blake, D., \& Starr, K. (2016). Understanding the nature of school partnerships with business in delivery of vocational programs in schools in Australia. Journal of Education and Work, doi:10.1080/13639080.2016.1165344.

Ryan, M., Brooks, J., \& Hooley, N. (2004). Evaluation of the Initial Statewide Implementation of the Victorial Certificate of Applied Learning. Victoria University.

Salamon, L. M. (2000). New Governance and the Tools of Public Action: An Introduction, Fordham Urban Law Journal, 28(5), 1611-1674.

Seddon, T., \& Billett, S. (2004). Social partnerships in vocational education: building community capacity. Adelaide: NCVER.

Seddon, T., Clemans, A., \& Billett, S. (2005). Social partnerships: Practices, paradoxes and prospects of Local Learning networks. The Australian Educational Researcher, 32(1), 25-48. doi:10.1007/bf03216811

Sorensen, E., \& Torfing, J. (2007). Theories of democratic network governance. Basingstoke: Palgrave Macmillan.

Stevens, P.A. \& Van Houte, M. (2010). Adapting to the System of the Student: Exploring Teacher Adaptations to Disadvantaged Students in an English and a Belgian Secondary School. Educational Evaluation and Policy Analysis, 33(1), 59-75.

Stokes, H., Stacey, K., \& Lake, M. (2006). Schools, Vocational Education and Training and Partnerships: Capacity-building in rural and regional communities. Adelaide: NCVER.

Suggett, D. (2014). Networking as System Policy. Balancing Vertical and Horizontal Dimensions. Victoria: Centre for Educational Research and Innovation.

Taylor, A. (2006). The challenges of partnership in school to work transition. Journal of Vocational Education \& Training, 58(3), 319-336. doi:10.1080/13636820600955716

Te Riele, K. \& Crump, S. (2002). Young people, education and hope: bringing VET in from the margins. International Journal of Inclusive Education, 6(3), 251-66.

Te Riele, K. (2012). Learning Choices: A map for the future. Sydney: Dusseldorp Skills Forum.

Turner. L. (1994). Social partnerships: An organising concept for industrial relations reform (Electronic version). Workplace Topics, 4(1), 83-97.

Wanna, J. (2008). Collaborative government: meanings, dimensions, drivers and outcomes. In J. O'Flynn, \& J. Wanna (Eds.), Collaborative Governance. A new era of public policy in Australia? (pp. 3-12). Canberra: ANU E Press.

Wheelahan, L. (2012). Why knowledge matters in curriculum. New York, NY: Routledge.

Whitty, G., \& Wisby, E. (2016). Education in England - a testbed for network governance? Oxford Review of Education, 42(3), 316-329.

Woolcock, M. (2001). The Place of Social Capital in Understanding Social and Economic Outcomes. ISUMA Canadian Journal of Policy Research 2(1), 11-17.

YacVic, (2011). Innovative learning options and the rural youth sector. Melbourne: Youth Affairs Council of Victoria and Victorian Rural Youth Services.

Young, M., \& Muller, J. (2010). Three educational scenarios for the future: Lessons from the sociology of knowledge. European Journal of Education 45(1), 11-27. 



\section{University Library}

\section{- M M N E R VA A gateway to Melbourne's research publications}

Minerva Access is the Institutional Repository of The University of Melbourne

Author/s:

Klatt, G;Angelico, T;Polesel, J

Title:

Emerging partnership practices in VET provision in the senior years of schooling in Australia

Date:

2018-04-01

Citation:

Klatt, G., Angelico, T. \& Polesel, J. (2018). Emerging partnership practices in VET provision in the senior years of schooling in Australia. AUSTRALIAN EDUCATIONAL RESEARCHER, 45 (2), pp.217-236. https://doi.org/10.1007/s13384-017-0244-9.

Persistent Link:

http://hdl.handle.net/11343/283097 